\title{
Decreased levels of serum glutathione peroxidase 3 are associated with papillary serous ovarian cancer and disease progression
}

Deep Agnani ${ }^{1}$, Olga Camacho-Vanegas' ${ }^{1}$ Catalina Camacho ${ }^{1}$, Shashi Lele ${ }^{2}$, Kunle Odunsi $^{2}$, Samantha Cohen $^{3}$, Peter Dottino ${ }^{3}$ and John A Martignetti ${ }^{1,4,5^{*}}$

\begin{abstract}
Background: Glutathione peroxidase 3 (GPX3) is a selenocysteine-containing antioxidant enzyme that reacts with hydrogen peroxide and soluble fatty acid hydroperoxides, thereby helping to maintain redox balance within cells. Serum levels of GPX3 have been found to be reduced in various cancers including prostrate, thyroid, colorectal, breast and gastric cancers. Intriguingly, GPX3 has been reported to be upregulated in clear cell ovarian cancer tissues and thus may have implications in chemotherapeutic resistance. Since clear cell and serous subtypes of ovarian cancer represent two distinct disease entities, the aim of this study was to determine GPX3 levels in serous ovarian cancer patients and establish its potential as a biomarker for detection and/or surveillance of papillary serous ovarian cancer, the most frequent form of ovarian tumors in women.
\end{abstract}

Patients and Methods: Serum was obtained from 66 patients (median age: 62 years, range: 22-89) prior to surgery and 65 controls with a comparable age-range (median age: 53 years, range: 25-83). ELISA was used to determine the levels of serum GPX3. The Mann Whitney $U$ test was performed to determine statistical significance between the levels of serum GPX3 in patients and controls.

Results: Serum levels of GPX3 were found to be significantly lower in patients than controls $\left(p=1 \times 10^{-2}\right)$. Furthermore, this was found to be dependent on the stage of disease. While levels in early stage (I/II) patients showed no significant difference when compared to controls, there was a significant reduction in late stage (III/IV, $\left.p=9 \times 10^{-4}\right)$ and recurrent $\left(p=1 \times 10^{-2}\right)$ patients. There was a statistically significant reduction in levels of GPX3 between early and late stage $\left(p=5 \times 10^{-4}\right)$ as well as early and recurrent $\left(p=1 \times 10^{-2}\right)$ patients. Comparison of women and controls stratified to include only women at or above 50 years of age shows that the same trends were maintained and the differences became more statistically significant.

Conclusions: Serum GPX3 levels are decreased in women with papillary serous ovarian cancer in a stagedependent manner and also decreased in women with disease recurrence. Whether this decrease represents a general feature in response to the disease or a link to the progression of the cancer is unknown. Understanding this relationship may have clinical and therapeutic consequences for women with papillary serous adenocarcinoma.

Keywords: Ovarian cancer, Papillary serous carcinoma, Glutathione peroxidase 3, GPX3

\footnotetext{
* Correspondence: John.martignetti@mssm.edu

'Department of Genetics and Genomic Sciences, Mount Sinai School of

Medicine, New York, NY 10029, USA

Full list of author information is available at the end of the article
} 


\section{Background}

Epithelial ovarian cancer (EOC) is the most lethal of all gynecologic cancers and the fifth most frequent cause of female cancer deaths [1]. It is estimated that over 21,000 new cases and 13,000 deaths will be attributed to the disease in 2011 alone [1]. Although 5-year survival rates have increased over the past several decades to approximately $40 \%$, overall mortality rates remain relatively constant [1] largely because most women present late in disease course with widespread intra-abdominal metastasis. Five-year relative survival rates drop from $>90 \%$ for disease diagnosed at an early stage to $<30 \%$ for disease diagnosed in later stages [2].

Currently, no serum biomarker has been FDA approved for the early detection of ovarian cancer whereas CA125 and the recently approved human epididymis protein 4 (HE4) are being utilized to monitor disease progress [2,3]. While several biomarkers/panels of biomarkers with reported higher sensitivities and specificities than CA125 are being investigated, none of these have improved upon the low efficacy of the measurement of CA125 levels in distinguishing ovarian cancer patients from controls during the asymptomatic stages of the disease [4-10]. Recently, the OVA $1^{\mathrm{TM}}$ test representing a biomarker panel and analysis based on menopausal status has received FDA approval for preoperative evaluation of ovarian cancer risk in women with an ovarian mass [11]. Interestingly, levels of three of the five biomarkers, apolipoprotein, prealbumin and transferrin, decrease in women with malignancy. This suggests that the search for biomarkers should expand beyond tumor-specific overexpressed proteins.

Tumor growth results in oxidative stress, accompanied by an increase in reactive oxygen species (ROS). ROS serve as secondary messenger molecules and may result in increased cellular proliferation, an increase in genetic mutations and overall genetic instability, increased cellular invasion and angiogenesis [12]. ROS are also known to stimulate pathways that may lead to development of drug resistance in cancer cells [13]. Higher levels of ROS are, however, toxic to cells and cancer treatments often employ strategies to increase ROS production [14]. Increases in the levels of ROS also lead to the increase in transcription of antioxidant enzymes including catalase, superoxide dismutase, glutathione- $S$-transferase, and glutathione peroxidase [12-16]. Thus the differential expression of antioxidant enzymes in cancer could serve as biomarkers of disease initiation and/or progression.

One antioxidant enzyme whose expression in serum/ plasma has been correlated with various cancers is glutathione peroxidase 3 (GPX3) [17]. A number of studies have shown GPX3 activity to be downregulated in patients with breast, gastric and colorectal cancers [18]. GPX3 was also found to be uniformly downregulated in all grades of endometrial adenocarcinoma, both in rats as well as humans, irrespective of tumor grade [19]. Furthermore, sera of glioblastoma patients appear to have lower levels of GPX3 when compared to controls [20]. On a genetic level, downregulation of GPX3 via hypermethylation of its promoter has been described in human esophageal squamous cell carcinoma tissue [21] and primary prostrate cancer samples and cell lines [22,23].

Intriguingly, previous studies have shown that compared to control tissues GPX3 expression is higher in clear cell epithelial ovarian carcinoma tissue [24-26]. Clear cell cancers account for approximately $5 \%$ of all ovarian cancers. The most common histology of ovarian cancer is papillary serous $(>60 \%)$ and the other histologies include endometrioid ( 25\%) and mucinous ( $5 \%)$ cancers. A proteomic analysis of women with stage IV papillary serous carcinoma who had been previously treated with surgery and chemotherapy also revealed the presence of GPX3 in their ascites fluid [27]. It is important to note that serum levels of GPX3 were not examined in either the clear cell or late-stage previously treated studies. Given that papillary serous epithelial ovarian cancer represents the majority of ovarian tumors and that no previous studies have examined serum GPX3 levels in women with this histology of ovarian cancer, we therefore hypothesized that GPX3 may represent a novel biomarker for this disease.

\section{Materials and methods}

\section{Serum sample collection}

A total of 66 serum samples from patients and 65 serum samples from controls with a comparable age-range were examined. Serum samples were obtained from three different sources: Twenty-eight (20/22 early, and 8/31 late stage) patient samples were from the Roswell Park Cancer Institute, Buffalo, NY, USA; twenty (20/65) control serum samples were commercially obtained from Bioserve Biotechnologies, Ltd. (Beltsville, MD, USA). All other samples, along with the relevant clinical data, were obtained from blood samples collected at the Mount Sinai School of Medicine (MSSM). Studies were approved by the respective medical ethics committees.

At MSSM, blood samples were collected in BD Vacutainer SSTTM Plus Blood Collection Tubes (BD Biosciences, USA). Samples were spun down at $2600 \mathrm{rpm}$ for $10 \mathrm{~min}$ utes at $4^{\circ} \mathrm{C}$ in Eppendorf 5810R centrifuge (Eppendorf, USA) to separate serum. Samples were then stored at $-130^{\circ} \mathrm{C}$ until ELISA assay was performed.

\section{ELISA assay}

Commercially available ELISA kits for measuring concentrations of GPX3, manufactured by Adipogen ${ }^{\mathrm{TM}}$ and supplied by ENZO Lifesciences, USA were obtained. All 
samples were diluted at 1:250 ratio in buffer provided in the kit. Assays were performed as per manufacturers' instructions, using the provided standard curve reagents. Controls and samples were run in duplicate to assure consistency. Intra-sample variability was less than $10 \%$.

\section{Statistical analyses}

A two-sided Mann-Whitney $U$ test was performed in MATLAB R2009B (The Mathworks, Inc., Natick, MA, USA) to compare GPX3 levels between groups. A pvalue of less than 0.05 was considered to be statistically significant. All box-plots were performed using Excel.

\section{Results}

\section{Patients}

Serum samples from 66 patients with pathology-confirmed papillary serous ovarian cancer and 65 healthy controls were examined. Patient characteristics are shown in Table 1 . The median age for the patients was 62 years (range: 22-89) while that of the controls was 53 (range: 25-83). Incorporated into the analysis were clinical factors including age, stage of disease and histological grade. As shown in Table 1, we selected for a higher number of early stage samples beyond the usual expected frequency of these cases in an unbiased population to specifically determine if there was a significant change in the levels of GPX3 in these samples.

\section{GPX3 serum levels are lower in patients when compared} to controls

A Mann Whitney $U$ test was performed comparing GPX3 concentrations between serum from all patients and controls. GPX3 concentrations were significantly lower in patients than controls (median value of $22.4 \mathrm{ng} / \mathrm{ml}$ in patients, compared to $27.8 \mathrm{ng} / \mathrm{ml}$ in controls, $\mathrm{p}=1 \times 10^{-2}$, Figure 1A). We next explored if GPX3 levels correlated with stage (Figure 1B). Women with late stage disease (median, $18.5 \mathrm{ng} / \mathrm{ml} ; \mathrm{p}=9 \times 10^{-4}$ ) and recurrence of their cancer (median, $14.7 \mathrm{ng} / \mathrm{ml} ; \mathrm{p}=1 \times 10^{-2}$ ) had significantly lower levels of GPX3 than controls. No difference was identified between women with early stage disease and controls $(\mathrm{p}=0.6)$. In addition women with late stage disease $(\mathrm{p}=5$ $\left.\times 10^{-4}\right)$ and recurrence of their cancer $\left(\mathrm{p}=1 \times 10^{-2}\right)$ had significantly lower levels of GPX3 than women with early stage disease. These results are summarized in Table 2.

Since most ovarian cancer cases are diagnosed in postmenopausal women, we next compared the levels of GPX3 between controls and patients such that we included only women $\geq 50$ years of age in each group. When stratified by age, GPX3 levels were even more significantly lower in all patients $(21.4 \mathrm{ng} / \mathrm{ml})$ when compared to controls $\left(36.1 \mathrm{ng} / \mathrm{ml} ; \mathrm{p}=3 \times 10^{-4}\right)$. In this age-delimited population, the differences were again even more significant in women with late stage disease (median, $18.5 \mathrm{ng} / \mathrm{ml} ; \mathrm{p}=1 \times 10^{-4}$ ) and recurrence (median, $\left.14.7 \mathrm{ng} / \mathrm{ml} ; \mathrm{p}=7 \times 10^{-4}\right)$. A statistically significant reduction in levels of GPX3 in patients diagnosed with late stage $\left(\mathrm{p}=5 \times 10^{-4}\right)$ and recurrent disease $(\mathrm{p}=1 \times$ $10^{-3}$ ) when compared to those diagnosed with early stage disease was again present. These results are summarized in Table 3.

No statistically significant correlations of GPX3 concentrations were identified with age, ethnicity or grade of disease (data not shown).

Table 1 Sample demographics and clinicopathologic characteristics

\begin{tabular}{|c|c|c|}
\hline Characteristic & Number of Patients (\%) & Number of Controls (\%) \\
\hline \multicolumn{3}{|l|}{ Ethnicity } \\
\hline Caucasian & $28(42.4)$ & $27(41.6)$ \\
\hline African-American & $2(3)$ & $1(1.5)$ \\
\hline Other & $6(9.1)$ & $1(1.5)$ \\
\hline Unknown & $30(45.5)$ & $36(55.4)$ \\
\hline \multicolumn{3}{|l|}{ Age (Years) } \\
\hline Median & 62 (range: 22-89) & $53^{*}$ (range: $25-83$ ) \\
\hline \multicolumn{3}{|l|}{ Ovarian Cancer Stage } \\
\hline Early (Stage 1/2) & $22(33)$ & \\
\hline Late (Stage 3/4) & $31(47)$ & \\
\hline Recurrent & $13(20)$ & \\
\hline \multicolumn{3}{|l|}{ Histological Grade } \\
\hline Well differentiated (1) & $6(9)$ & \\
\hline Moderately Differentiated (2) & $15(23)$ & \\
\hline Poorly differentiated (3) & $39(59)$ & \\
\hline Unknown & $6(9)$ & \\
\hline
\end{tabular}

\footnotetext{
* $\mathrm{n}=50$; age of 15 controls had not been recorded. The values in brackets represent percentage to total.
} 

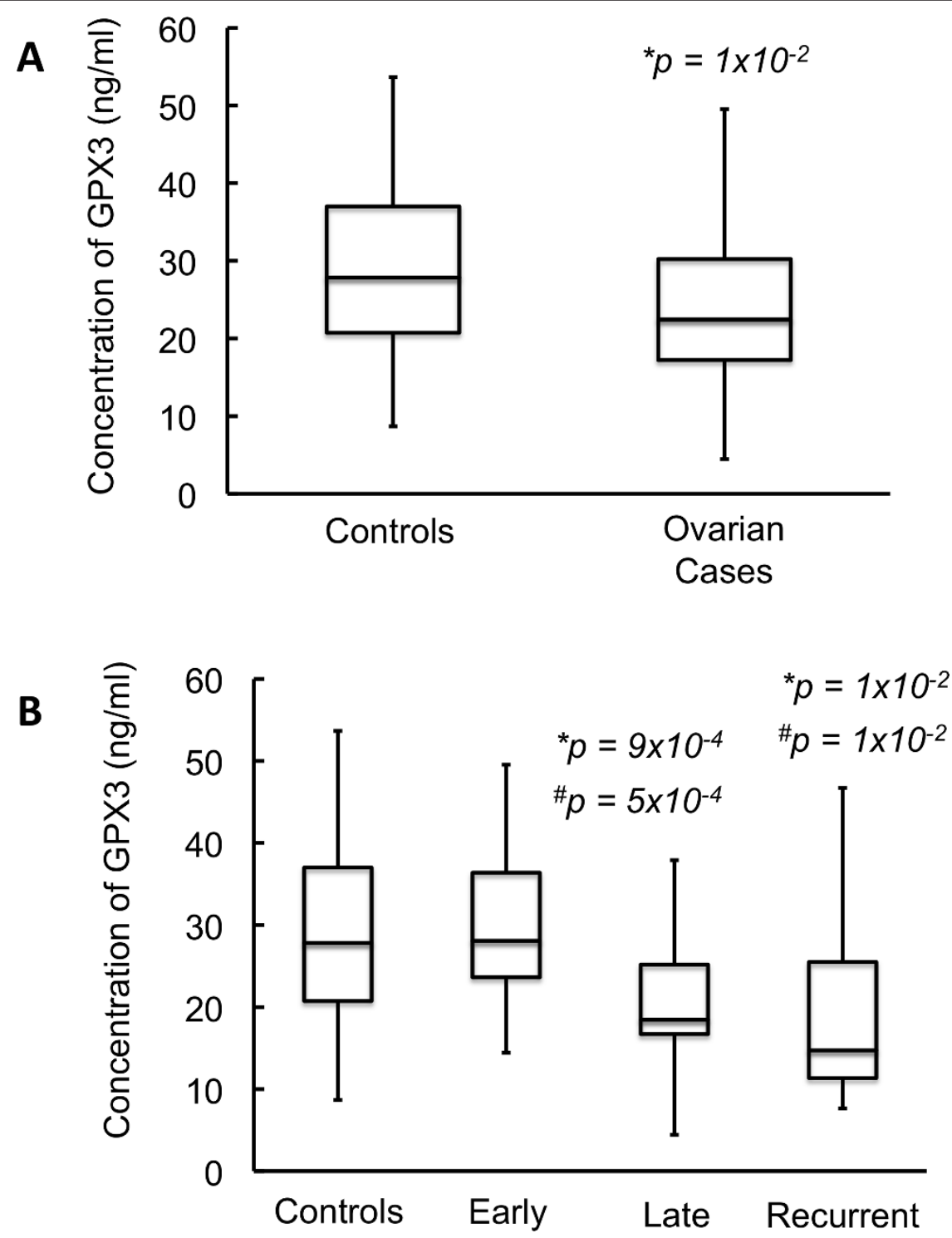

Figure 1 Comparison of GPX3 levels of healthy female controls vs. women with serous ovarian cancer for women of all ages: Figure 1 A shows a group-wise comparison of GPX3 in healthy female controls vs. women diagnosed with papillary serous ovarian cancer while Figure 1B shows a stage-wise comparison of GPX3 in healthy female controls vs. women diagnosed with papillary serous ovarian cancer. Star $\left(^{*}\right)$ denotes statistically significant decrease in GPX3 expression when compared to controls. Hash (\#) denotes statistically significant difference in GPX3 expression when compared to early stage samples. Women diagnosed with serous ovarian cancer show a statistically significant decrease in the levels of GPX3. A stage-wise examination shows that there is a significant decrease in GPX3 levels in late stage and recurrent cancer. There is also a significant difference in levels of GPX3 between patients with early and late stage/recurrent disease.

Table 2 Summary of data from Figure $1 \mathrm{~A}$ and $1 \mathrm{~B}$

\begin{tabular}{|c|c|c|c|c|c|}
\hline Variable & Control & All Patients & Early & Late & Recurrent \\
\hline Number of samples $(n)$ & 65 & 66 & 22 & 31 & 13 \\
\hline \multicolumn{6}{|c|}{ GPX3 concentration $(\mathrm{ng} / \mathrm{ml})$} \\
\hline Median & 27.8 & 22.4 & 28.1 & 18.5 & 14.7 \\
\hline Maximum & 53.7 & 49.5 & 49.5 & 44.6 & 48.9 \\
\hline Minimum & 8.7 & 4.5 & 14.4 & 4.5 & 7.7 \\
\hline \multicolumn{6}{|c|}{ Statistical Analysis: Mann Whitney $U$ test (p-value) } \\
\hline Vs. Controls & & $1 \times 10^{-2}$ & 0.6 & $9 \times 10^{-4}$ & $1 \times 10^{-2}$ \\
\hline Vs. Early stage samples & & & & $5 \times 10^{-4}$ & $1 \times 10^{-2}$ \\
\hline
\end{tabular}

Comparison of all samples indicates that GPX3 levels significantly decrease in patients and are correlated with stage. $\mathrm{p}$-values indicating statistically significant differences are shown in bold. 

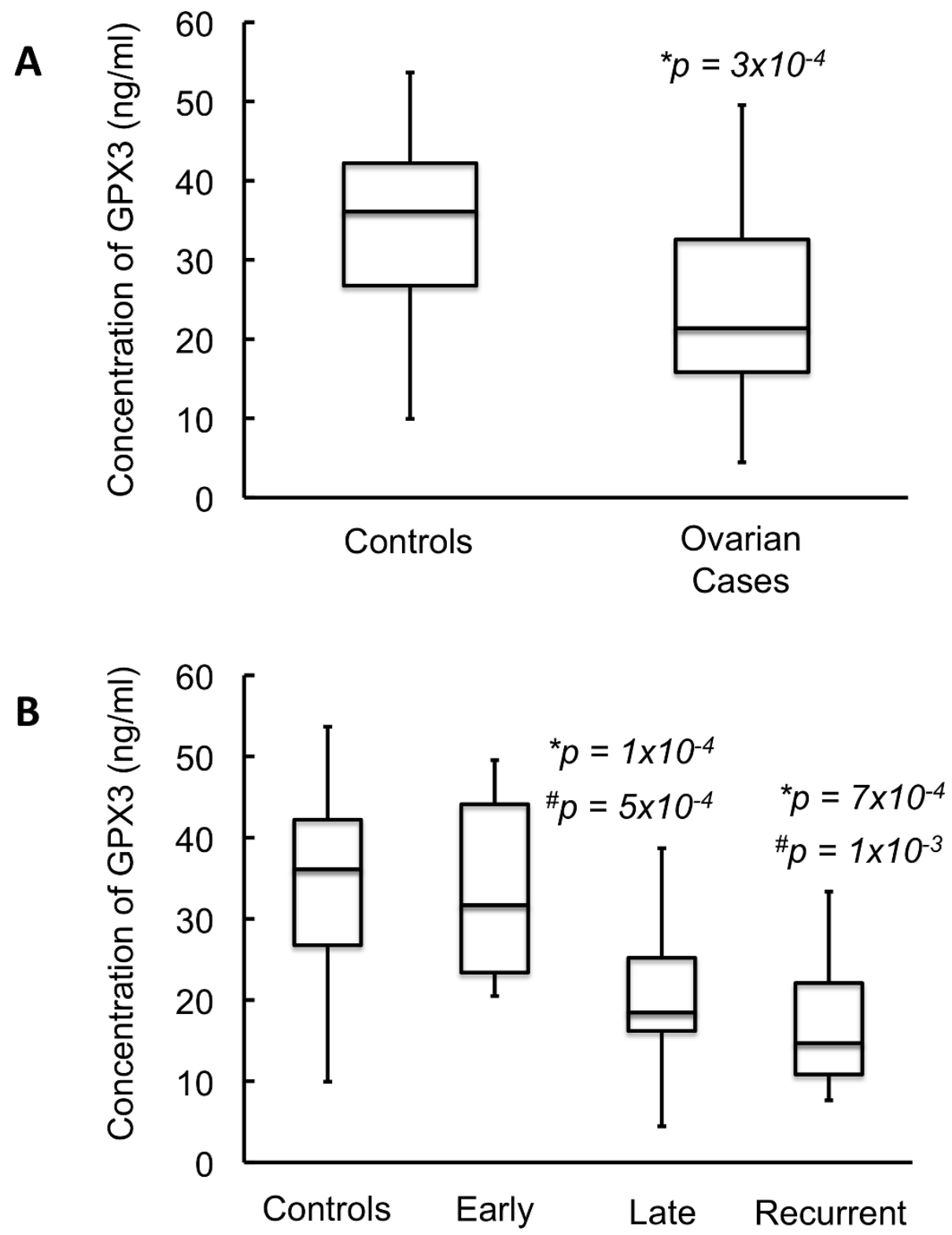

Figure 2 Comparison of GPX3 levels of healthy female controls vs. women with serous ovarian cancer $\geq 50$ years of age (average age of menopause): Figure 2A shows a group-wise comparison of GPX3 in healthy female controls vs. women diagnosed with papillary serous ovarian cancer while Figure 2B shows a stage-wise comparison of GPX3 in healthy female controls vs. women diagnosed with papillary serous ovarian cancer. Star $\left(^{*}\right)$ denotes statistically significant decrease in GPX3 expression when compared to controls. Hash (\#) denotes statistically significant difference in GPX3 expression when compared to early stage samples. Women diagnosed with serous ovarian cancer show a statistically significant decrease in the levels of GPX3. A stage-wise examination shows that there is a significant decrease in GPX3 levels in late stage and recurrent cancer. There is also a significant difference in levels of GPX3 between patients with early and late stage/ recurrent disease.

\section{Discussion}

Using a candidate-based approach, and samples from 3 independent sources, we have identified that the serum protein GPX3, a selenocysteine-containing antioxidant enzyme, is decreased in women with serous ovarian cancer in a stage-dependent manner. In addition, we demonstrate that serum levels are also decreased in women with recurrent disease and the stage-dependent decreases are more pronounced when patients and controls are stratified to include only those women $>50$ years of age. Thus, while a number of other studies have examined GPX3 levels in a broad array of cancer (Table 4), these studies provide the first analysis of this candidate biomarker in epithelial ovarian cancer, specifically, 
Table 3 Summary of data from Figure 2A and 2B

\begin{tabular}{|c|c|c|c|c|c|}
\hline Variable & Control & All Patients & Early & Late & Recurrent \\
\hline Number of samples $(n)$ & 30 & 56 & 16 & 29 & 11 \\
\hline \multicolumn{6}{|l|}{ GPX3 concentration $(\mathrm{ng} / \mathrm{ml})$} \\
\hline Median & 36.1 & 21.4 & 31.7 & 18.5 & 14.7 \\
\hline Maximum & 53.7 & 49.5 & 49.5 & 44.6 & 33.4 \\
\hline Minimum & 9.9 & 4.5 & 20.5 & 4.5 & 7.7 \\
\hline \multicolumn{6}{|c|}{ Statistical Analysis: Mann Whitney $U$ test (p-value) } \\
\hline Vs. Controls & & $3 \times 10^{-4}$ & 0.5 & $1 \times 10^{-4}$ & $7 \times 10^{-4}$ \\
\hline Vs. Early stage samples & & & & $5 \times 10^{-4}$ & $1 \times 10^{-3}$ \\
\hline
\end{tabular}

Comparison of samples $\geq 50$ years indicates that GPX3 levels significantly decrease in patients and are correlated with stage with an even greater statistical significance than that seen in Table 1. p-values indicating statistically significant differences are shown in bold.

the serum of women with papillary serous ovarian cancer.

Oncogenesis is associated with an increase in the intracellular levels of ROS, in turn resulting in an upregulation of antioxidant enzymes [12-16]. However, several studies conducted on tissue as well as blood/serum samples have shown that levels of the antioxidant enzyme GPX3 are decreased in a number of human cancers, including breast, gastric, prostrate and colorectal cancer; a seemingly contradictory effect [18-21,28,29]. A number of recent studies in clear cell ovarian cancer tissues conducted by others have identified a higher expression of GPX3 when compared to control cells and in other epithelial ovarian cancer histologies [24-26]. This not only suggests a potential anomaly but also could have therapeutic consequences since higher levels of GPX3 have been shown to confer chemotherapeutic resistance in cells [25]. The only other study performed in papillary serous cancer examined the ascites fluid of women with advanced stage disease after their treatment with surgery and chemotherapy and who were being treated for removal of an accumulation of ascites fluid [27]. Since serous ovarian cancer represents the most common epithelial ovarian cancer histology, we wanted to specifically examine the serum levels of this epithelial ovarian cancer subtype.

Our results demonstrate that serum GPX3 is downregulated in serous ovarian cancer. More importantly we identified a statistically significant difference in GPX3 levels between early and late stage/recurrent patients, suggesting that GPX3 may serve as a biomarker of

Table 4 GPX3 associations with cancer

\begin{tabular}{|c|c|c|c|c|c|}
\hline Cancer Type & $\begin{array}{l}\text { Overexpression/ } \\
\text { Downregulation }\end{array}$ & $\begin{array}{l}\text { RNA/ } \\
\text { Protein }\end{array}$ & $\begin{array}{c}\text { Cell/Tissue/ } \\
\text { Serum/Plasma }\end{array}$ & Species & References \\
\hline Esophageal Squamous Cell & Downregulation & $\begin{array}{l}\text { mRNA, } \\
\text { protein }\end{array}$ & Tumor tissue & Human & {$[31]$} \\
\hline $\begin{array}{c}\text { Gastric, Cervical, Thyroid, Head, Neck, Lung and } \\
\text { Melanoma }\end{array}$ & Downregulation & $\begin{array}{l}\text { mRNA, } \\
\text { protein }\end{array}$ & Tumor tissue & Human & {$[32]$} \\
\hline Thyroid & Downregulation & mRNA & Tumor tissue & Human & [33] \\
\hline Ovarian Clear Cell & Upregulation & mRNA & Cell Lines & Human & {$[25]$} \\
\hline Ovarian Clear Cell & Upregulation & $\begin{array}{l}\text { mRNA, } \\
\text { protein }\end{array}$ & Tumor tissue & Human & {$[24]$} \\
\hline Ovarian Clear Cell & Upregulation & mRNA & Tumor tissue & Human & {$[26]$} \\
\hline $\begin{array}{c}\text { Ovarian Papillary Serous: Late Stage/previously } \\
\text { treated }\end{array}$ & Presence & Protein & Ascites Fluid & Human & {$[27]$} \\
\hline Glioblastoma & Downregulation & $\begin{array}{l}\text { mRNA, } \\
\text { protein }\end{array}$ & Tumor tissue, Serum & Human & {$[20]$} \\
\hline Meningioma & Downregulation & mRNA & Tumor Tissue & Human & [34] \\
\hline Lung & Downregulation & protein & $\begin{array}{c}\text { Whole blood, Plasma (activity } \\
\text { measurement) }\end{array}$ & Human & [35] \\
\hline Endometrial adenocarcinoma & Downregulation & mRNA & Tumor Tissue & $\begin{array}{l}\text { Human, } \\
\text { Rat }\end{array}$ & [19] \\
\hline Barrett's adenocarcinoma & Downregulation & mRNA & Tumor Tissue & Human & [36] \\
\hline Prostate & Downregulation & mRNA & Tumor tissue & Human & [23] \\
\hline Lung & Upregulation & protein & Blood serum & Mouse & {$[37]$} \\
\hline Prostate cancer & Upregulation & protein & Blood serum & $\begin{array}{l}\text { Human, } \\
\text { Rat }\end{array}$ & {$[38]$} \\
\hline
\end{tabular}


disease progression. These differences reach greatest statistical significance when patients/controls are stratified to include only women above 50 years of age, the age at which most cases are diagnosed.

It is interesting to note that inspection of our MSSM cohort identified a patient for whom GPX3 levels seemed more indicative of disease status than CA125. Specifically, one of our 58 year old women with stage IIIC disease had a CA125 level of $32.3 \mathrm{U} / \mathrm{ml}$ (within normal limits) but a low GPX3 level $(17.7 \mathrm{ng} / \mathrm{ml})$. It will therefore be interesting in the future to evaluate if GPX3 could be coupled with CA125 or other candidate biomarkers to increase their sensitivity and specificity.

Under normal conditions, ROS play a role in signal transduction $[12,13,16]$. However, higher levels of intracellular ROS can lead to increased DNA mutations that have been associated with increased carcinogenesis $[12,13]$.

Cellular studies indicate that GPX3 physiologically serves as a first line of defense reducing ROS to harmless species prior to their entry into the cell [29]. While our studies clearly define decreased serum GPX3 levels in women with ovarian cancer, we are not able to distinguish whether the decrease may represent a risk factor for the development of the cancer or simply represents a systemic response to the disease. If the decrease is a risk factor, could GPX3 be used as a screening tool or could increases in GPX3 reduce lifetime risk? Similarly, if the decrease represents a response to the disease, do patients with different GPX3 levels have different disease outcomes or health sequelae? For example, in a study on critically ill patients in an intensive care setting, decreased GPX3 levels were associated with a systemic inflammatory response syndrome (SIRS) [30]. Thus important future studies will be validating these results and in exploring the role of GPX3 in cancer initiation, progression and outcome.

In conclusion, this study demonstrates that serum GPX3 levels are reduced in papillary serous ovarian cancer patients when compared to controls and that, at least in one instance, decreased levels of GPX3 may provide additional diagnostic information beyond CA125.

\footnotetext{
Abbreviations

CA125: Mucin 16, cell surface associated; GPX3: Glutathione peroxidase 3: HE4: Human epididymis protein 4; MSSM: Mount Sinai School of Medicine; ROS: Reactive oxygen species; SIRS: Systemic inflammatory response syndrome
}

\section{Acknowledgements}

This study was supported in part by an Ovarian Cancer Research Fund grant through the generous support of the Gordon Family to PD and JAM.

\section{Author details}

${ }^{1}$ Department of Genetics and Genomic Sciences, Mount Sinai School of Medicine, New York, NY 10029, USA. ²Department of Gynecologic Oncology,
Roswell Park Cancer Institute, Buffalo, New York 14263, USA. ${ }^{3}$ Department of Obstetrics, Gynecology, and Reproductive Science, Mount Sinai School of

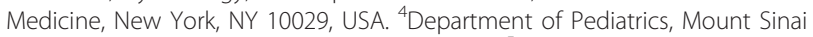
School of Medicine, New York, NY 10029, USA. ${ }^{5}$ Department of Oncological Sciences, Mount Sinai School of Medicine, New York, NY 10029, USA.

\section{Authors' contributions}

DA conceptualized and designed the experiments, collected, assembled, analyzed and interpreted data, and drafted the manuscript. OC conceptualized and designed the experiments, and collected, assembled and analyzed data. CC designed and implemented experiments. SS recruited, collected and annotated specimens, and interpreted data. $\mathrm{KO}$ recruited, collected and annotated specimens, and interpreted data. SC collected and annotated specimens, and analyzed and interpreted data. PD conceptualized and designed the experiments, analyzed and interpreted data, and helped with the drafting of manuscript. JM conceptualized and designed the experiments, analyzed and interpreted data, and helped with the drafting of manuscript. All the authors in this manuscript have read and approved the final version.

\section{Competing interests}

The authors declare that they have no competing interests.

Received: 18 August 2011 Accepted: 22 October 2011

Published: 22 October 2011

\section{References}

1. Jemal A, Bray F, Center MM, Ferlay J, Ward E, Forman D: Global Cancer statistics. CA Cancer J Clin 2011, 61:69-90.

2. Ovarian Cancer Home Page-National Cancer Institute. [http://www.cancer. gov/cancertopics/types/ovarian].

3. Kim YM, Whang DH, Park J, Kim SH, Lee SW, Park HA, Ha M, Choi KH: Evaluation of the accuracy of serum human epididymis protein 4 in combination with CA125 for detecting ovarian cancer: a prospective case-control study in a Korean population. Clin Chem Lab Med 2011, 49:527-534.

4. Zhu CS, Pinsky PF, Cramer DW, Ransohoff DF, Hartge P, Pfeiffer RM, Urban N, Mor G, Bast RC Jr, Moore LE, Lokshin AE, Mclntosh MW, Skates SJ, Vitonis A, Zhang Z, Ward DC, Symanowski JT, Lomakin A, Fung ET, Sluss PM, Scholler N, Lu KH, Marrangoni AM, Patriotis C, Srivastava S, Buys SS, Berg CD, PLCO Project Team: A Framework for evaluating biomarkers for early detection: validation of biomarker panels for ovarian cancer. Cancer Prev Res (Phila) 2011, 4:375-383.

5. Cramer DW, Bast RC Jr, Berg CD, Diamandis EP, Godwin AK, Hartge P, Lokshin AE, Lu KH, McIntosh MW, Mor G, Patriotis C, Pinsky PF, Thornquist MD, Scholler N, Skates SJ, Sluss PM, Srivastava S, Ward DC, Zhang Z, Zhu CS, Urban N: Ovarian cancer biomarker performance in prostate, lung, colorectal, and ovarian cancer screening trial specimens. Cancer Prev Res (Phila) 2011, 4:365-374.

6. Mai PL, Wentzensen N, Greene MH: Challenges related to developing serum-based biomarkers for early ovarian cancer detection. Cancer Prev Res (Phila) 2011, 4:303-306.

7. Petricoin EF, Ardekani AM, Hitt BA, et al: Use of proteomic patterns in serum to identify ovarian cancer. Lancet 2002, 359:572-577.

8. Zhang Z, Bast RC Jr, Yu Y, Li J, Sokoll LJ, Rai AJ, Rosenzweig JM, Cameron B, Wang YY, Meng XY, Berchuck A, Van Haaften-Day C, Hacker NF, de Bruijn HW, van der Zee AG, Jacobs IJ, Fung ET, Chan DW: Three biomarkers identified from serum proteomic analysis for the detection of early stage ovarian cancer. Cancer Res 2004, 64:5882-5890.

9. Gorelik E, Landsittel DP, Marrangoni AM, Modugno F, Velikokhatnaya L, Winans MT, Bigbee WL, Herberman RB, Lokshin AE: Multiplexed immunobead-based cytokine profiling for early detection of ovarian cancer. Cancer Epidemiol Biomarkers Prev 2005, 14:981-987.

10. Visintin I, Feng Z, Longton G, Ward DC, Alvero AB, Lai $Y$, Tenthorey J, Leiser A, Flores-Saaib R, Yu H, Azori M, Rutherford T, Schwartz PE, Mor G: Diagnostic markers for early detection of ovarian cancer. Clin Cancer Res 2008, 14:1065-1072.

11. Zhang Z, Chan DW: The road from discovery to clinical diagnostics: lessons learned from the first FDA-cleared in vitro diagnostic multivariate index assay of proteomic biomarkers. Cancer Epidemiol Biomarkers Prev 2010, 19:2995-2999. 
12. Azad MB, Chen Y, Gibson SB: Regulation of autophagy by reactive oxygen species (ROS): Implications for cancer progression and treatment. Antioxid Redox Signal 2009, 11:777-790.

13. Pelicano H, Carney D, Huang P: ROS stress in cancer cells and therapeutic implications. Drug Resist Updat 2004, 7:97-110.

14. Harris AL: Hypoxia-A key regulatory factor in tumor growth. Nat Rev Cancer 2002, 2:38-47

15. Tertil M, Jozkowicz A, Dulak J: Oxidative stress in tumor angiogenesistherapeutic targets. Curr Pharm Des 2010, 16:3877-3894.

16. Avni R, Cohen B, Neeman M: Hypoxic stress and cancer: imaging the axis of evil in tumor metastasis. NMR Biomed 2011.

17. Brigelius-Flohé R, Kipp A: Glutathione peroxidases in different stages of carcinogenesis. Biochim Biophys Acta 2009, 1790:1555-1568.

18. Pawłowicz Z, Zachara BA, Trafikowska U, Maciag A, Marchaluk E, Nowicki A: Blood selenium concentrations and glutathione peroxidase activities in patients with breast cancer and with advanced gastrointestinal cancer. J Trace Elem Electrolytes Health Dis 1991, 5:275-277.

19. Falck E, Karlsson S, Carlsson J, Helenius G, Karlsson M, Klinga-Levan K: Loss of glutathione peroxidase 3 expression is correlated with epigenetic mechanisms in endometrial adenocarcinoma. Cancer Cell Int 2010, 10:46-54.

20. Sreekanthreddy $P$, Srinivasan $H$, Kumar DM, Nijaguna MB, Sridevi S, Vrinda M, Arivazhagan A, Balasubramaniam A, Hegde AS, Chandramouli BA, Santosh V, Rao MR, Kondaiah P, Somasundaram K: Identification of potential serum biomarkers of glioblastoma: serum osteopontin levels correlate with poor prognosis. Cancer Epidemiol Biomarkers Prev 2010, 19:1409-1422.

21. He Y, Wang Y, Li P, Zhu S, Wang J, Zhang S: Identification of GPX3 epigenetically silenced by $\mathrm{CpG}$ methylation in human esophageal squamous cell carcinoma. Dig Dis Sci 2011, 56:681-688.

22. Lodygin D, Epanchintsev A, Menssen A, Diebold J, Hermeking H: Functional epigenomics identifies genes frequently silenced in prostate cancer. Cancer Res 2005, 15:4218-4227.

23. Yu YP, Yu G, Tseng G, Cieply K, Nelson J, Defrances M, Zarnegar R, Michalopoulos G, Luo JH: Glutathione peroxidase 3, deleted or methylated in prostate cancer, suppresses prostate cancer growth and metastasis. Cancer Res 2007, 67:8043-8050.

24. Lee HJ, Do JH, Bae S, Yang S, Zhang X, Lee A, Choi YJ, Park DC, Ahn WS: Immunohistochemical evidence for the over-expression of glutathione peroxidase 3 in clear cell type ovarian adenocarcinoma. Med Oncol 2010.

25. Saga Y, Ohwada M, Suzuki M, Konno R, Kigawa J, Ueno S, Mano H: Glutathione peroxidase 3 is a candidate mechanism of anticancer drug resistance of ovarian clear cell adenocarcinoma. Oncol Rep 2008, 20:1299-1303.

26. Hough CD, Cho KR, Zonderman AB, Schwartz DR, Morin PJ: Coordinately up-regulated genes in ovarian cancer. Cancer Res 2001, 61:3869-3876.

27. Kuk C, Kulasingam V, Gunawardana CG, Smith CR, Batruch I, Diamandis EP: Mining the Ovarian Cancer Ascites Proteome for Potential Ovarian Cancer Biomarkers. Mol Cell Proteomics 2009, 8:661-9.

28. Sarto C, Frutiger S, Cappellano F, Sanchez JC, Doro G, Catanzaro F, Hughes GJ, Hochstrasser DF, Mocarelli P: Modified expression of plasma glutathione peroxidase and manganese superoxide dismutase in human renal cell carcinoma. Electrophoresis 1999, 20:3458-3466.

29. Howie AF, Walker SW, Akesson B, Arthur JR, Beckett GJ: Thyroidal extracellular glutathione peroxidase: a potential regulator of thyroidhormone synthesis. Biochem J 1995, 308:713-717.

30. Manzanares W, Biestro A, Galusso F, Torre MH, Mañay N, Pittini G, Facchin G, Hardy G: Serum selenium and glutathione peroxidase-3 activity: biomarkers of systemic inflammation in the critically ill? Intensive Care Med 2009, 35:882-889.

31. Ye He Y, Wang Y, Li P, Zhu S, Wang J, Zhang S: Identification of GPX3 epigenetically silenced by $\mathrm{CpG}$ methylation in human esophageal squamous cell carcinoma. Dig Dis Sci 2011, 56:681-8.

32. Zhang X, Yang JJ, Kim YS, Kim KY, Ahn WS, Yang S: An 8-gene signature, including methylated and down-regulated glutathione peroxidase 3 , of gastric cancer. Int J Oncol 2010, 36:405-14.

33. Schmutzler C, Mentrup B, Schomburg L, Hoang-Vu C, Herzog V, Köhrle J: Selenoproteins of the thyroid gland: expression, localization and possible function of glutathione peroxidase 3. Biol Chem 2007, 388:1053-1059.
34. Fevre-Montange M, Champier J, Durand A, Wierinckx A, Honnorat J, Guyotat J, Jouvet A: Microarray gene expression profiling in meningiomas: differential expression according to grade or histopathological subtype. Int J Oncol 2009, 35:1395-4077.

35. Zachara BA, Marchaluk-Wisniewska E, Maciaq A, Peplinski J, Skokowski J, et al: Decreased selenium concentration and glutathione peroxidase activity in blood and increase of these parameters in malignant tissue of lung cancer patients. Lung 1997, 175:321-332.

36. Lee OJ, Schneider-Stock R, McChesney PA, Kuester D, Roessner A, Vieth M, Moskaluk CA, El-Rifai W: Hypermethylation and loss of expression of glutathione peroxidase-3 in Barrett's tumorigenesis. Neoplasia 2005, 7:854-61.

37. Chatterij B, Borlak J: A 2-DE MALDI-TOF study to identify disease regulated serum proteins in lung cancer of c-myc transgenic mice. Proteomics 2009, 9:1044-1056.

38. Fan Y, Murphy TB, Byrne JC, Brennan L, Fitzpatrick JM, Watson RWG Applying Random Forests To Identify Biomarker Panels in Serum 2DDIGE Data for the Detection and Staging of Prostate Cancer. J Proteome Res 2011, 10:1361-1373.

doi:10.1186/1757-2215-4-18

Cite this article as: Agnani et al:: Decreased levels of serum glutathione peroxidase 3 are associated with papillary serous ovarian cancer and disease progression. Journal of Ovarian Research 2011 4:18.

\section{Submit your next manuscript to BioMed Central and take full advantage of:}

- Convenient online submission

- Thorough peer review

- No space constraints or color figure charges

- Immediate publication on acceptance

- Inclusion in PubMed, CAS, Scopus and Google Scholar

- Research which is freely available for redistribution

Submit your manuscript at www.biomedcentral.com/submit
Ciomed Central 